\title{
Strategy of Promoting E-Learning in School Library
}

\author{
Tzong-Yue Chen \\ Director of Library \\ National Keelung Girls' Senior High School in Taiwan
}

In 1970, a Fortune magazine announced the names of top 500 enterprises and their performance in the United States. Ten years later, one third of them disappeared. Due to unprecedented technology progress and increase in competitiveness in last 20 years, so-called learning organization has become the most successful corporation. Hence, the ability to learn faster than your competitors may have become the only sustainable competitive advantage.So far schools have had difficulties to adapt enterprises' strategy to become 'learning school'. Using the unique characteristics and resources of a school and its community is a way to create competitive curricula. Moreover, teachers are encouraged to employ information technology (multi-media software tools) to create and edit teaching materials. In the near future, school library will play the important role to help readers to learn how to learn by software and hardware tools. Teacher librarians will set up Information Communication Technology platform, organize some reading club to improve their reading behavior, hold information literacy seed teachers contest to upgrade readers information literacy capability and researching conference.for exchanging experience Meanwhle, developing catalogue and classification standards for digital materials by IEEE's Draft Standard for Learning Object Metadata.provide informations for their readers from Internet and knowledge database, and learn the trend of fast advance of modern science and technology to make innovative activities..

\section{INTRODUCTION OF E-LEARNING}

In business, learning is a means to an end. Generally speaking, that end is enhanced workforce performance, which in turn reflects its value-better products and services, lower costs, a more competitive posture in the marketplace, greater innovation, improved productivity, increased market share, etc.

E-Learning refers to the use of Internet technologies to deliver a broad array of solutions that enhance knowledge and performance. It is based on three fundamental criteria:

1. E-Learning is networked, which makes it capable of instance updating, storage/retrieval, distribution and sharing of instruction or information.

2. It is delivered to the end-user via a computer using standard Internet technology. 
3. It focuses on the broadest view of learning-learning solutions that go beyond the traditional paradigms of training.

Benefits of E-Learning

\begin{tabular}{|c|c|}
\hline Benefits & Description \\
\hline E-Learning lowers cost & $\begin{array}{l}\text { It cuts travel expenses, reduces the time it takes to train } \\
\text { people, and eliminate or significantly reduces the need } \\
\text { for a classroom/instructor infrastructure }\end{array}$ \\
\hline $\begin{array}{l}\text { E-Learning enhances } \\
\text { business responsiveness }\end{array}$ & $\begin{array}{l}\text { E-Learning can reach an unlimited number of people } \\
\text { virtually simultaneously. This can be critical when } \\
\text { business practices and capabilities have to change fast. }\end{array}$ \\
\hline $\begin{array}{l}\text { Messages are consistent or } \\
\text { customized,dependenting on } \\
\text { need }\end{array}$ & $\begin{array}{l}\text { Everyone gets the same content, presented in the same } \\
\text { way. }\end{array}$ \\
\hline $\begin{array}{l}\text { Content is more timely } \\
\text { and dependable }\end{array}$ & $\begin{array}{l}\text { Because it's Web-enabled, e-learning can be updated } \\
\text { instantaneously, making the information more accurate } \\
\text { and useful for a longer period of time. }\end{array}$ \\
\hline Learning is $24 / 7$ & $\begin{array}{l}\text { People can access e-learning anywhere and any time. It's } \\
\text { "just in time-any time” approach makes an } \\
\text { organization's learning operations truly global. }\end{array}$ \\
\hline $\begin{array}{l}\text { No user "ramp-up" } \\
\text { time }\end{array}$ & $\begin{array}{l}\text { With so many millions of people already on the Web and } \\
\text { comfortable with browser technology, learning to access } \\
\text { e-learning is quickly becoming a non-issue. }\end{array}$ \\
\hline Universality & $\begin{array}{l}\text { E-Learning is Web-enabled and takes advantage of the } \\
\text { universal Internet protopcols and browsers. Concern over } \\
\text { differences in platform and operating systems is rapidly } \\
\text { fading. Everyone on the Web can receive virtually the } \\
\text { same material in virtually the same way. }\end{array}$ \\
\hline Builds community & $\begin{array}{l}\text { The Web enables people to build enduring communities } \\
\text { of practice where they can come together to share } \\
\text { knowledge and insight long after a training program } \\
\text { ends. }\end{array}$ \\
\hline Scalability & $\begin{array}{l}\text { E-Learning solutions are highly scalable. Program can } \\
\text { move from } 10 \text { participants to } 100 \text { or even } 100,000 \\
\text { participants with little effort or incremental cost. }\end{array}$ \\
\hline $\begin{array}{l}\text { Leverage the corporate } \\
\text { investment in the Web }\end{array}$ & $\begin{array}{l}\text { Executive are increasingly looking for ways to leverage } \\
\text { their hugh investment in corporate intranets. }\end{array}$ \\
\hline $\begin{array}{l}\text { Provides an increasingly } \\
\text { valuable customer service }\end{array}$ & $\begin{array}{l}\text { Although not internally focused, a business e-commerce } \\
\text { effort can be enhanced through the effective and }\end{array}$ \\
\hline
\end{tabular}




\begin{tabular}{|l|l|}
\hline & $\begin{array}{l}\text { engaging use of e-learning that helps customers derive } \\
\text { increased benefit from the site. }\end{array}$ \\
\hline
\end{tabular}

\section{INTRODUCTION OF CYBER LEARNING SCHOOL}

Cyber Learning School is an environment that includes hardware, software and pedagogy. It adds two new dimensions of mobility and situated learning to the traditional schooling concept, particularly when it utilizes information and communication technologies associated with distance learning.

There is a three-layer of architecture in setting up and running a Cyber Learning School:

1. Hardware setup, where computer hardware and networking devices are put together to create system infrastructure.

2. Software setup, where e-learning system is installed by using appropriate software tools like HABOOK and WebCT

3 Course setup, where online courses are designed and teachers and students undertake teaching and learning activities facilitated by e-learning system.

Cyber Learning School includes three elements: Cyber Learning Classroom, Cyber Teacher Desk, and Cyber Student Desk.

\section{Cyber Learning Classroom}

The Cyber Learning Classroom has many distinct advantages over the computer rooms that typical traditional schools generally have. Traditional schools generally have one computer room where teachers can take their students for some computer related activities. Such computer rooms remain fixed and therefore cannot be used for situated learning. They require students and teachers to move to separate room hence leaving all resources that are in the classroom, such as reference books,demonstration material, and other teaching aids. Basically, traditional computer rooms separate reality from virtual, whereas Cyber Learning Classrooms merge them together.

Cyber Learning Classroom are constructed under Cyber Learning School. Teachers can provide different courses in different Cyber Learning Classrooms. The resources of these courses can be digitalized and stored in the Cyber Learning School. In the Cyber Learning Classroom, teachers can manage various activities such as student interaction, teaching resources, assignments, students' tests, and students' results. On the other hand, students can interact in online synchronous or asynchronous teaching, have online synchronous or asynchronous discussion with classmates, submit their aasignment, take online tests, and emgage in other learning activities.

\section{Cyber Teacher Desk}

Cyber Teacher Desk is generally constructed of a Tablet PC or notebook computer, combined with the ability of wireless network connection and web camera.. With the help of 
teaching aid software, it also contains writing ability similar to that of a whiteboard, the function of immediate telecast, and of video recording. Besides, It provides teachers with no time and space restrictions, and also enriches teaching quality.

\section{Cyber Student Desk}

The construction of the Cyber Student Desk is similar to the Cyber Teacher Desk. It can be constructed using a Tablet PC or a notebook computer. Besides, it includes the ability of wireless internet, web camera, and the learning aid software that includes functions such as electronic notes making, dictionary, and calculator.

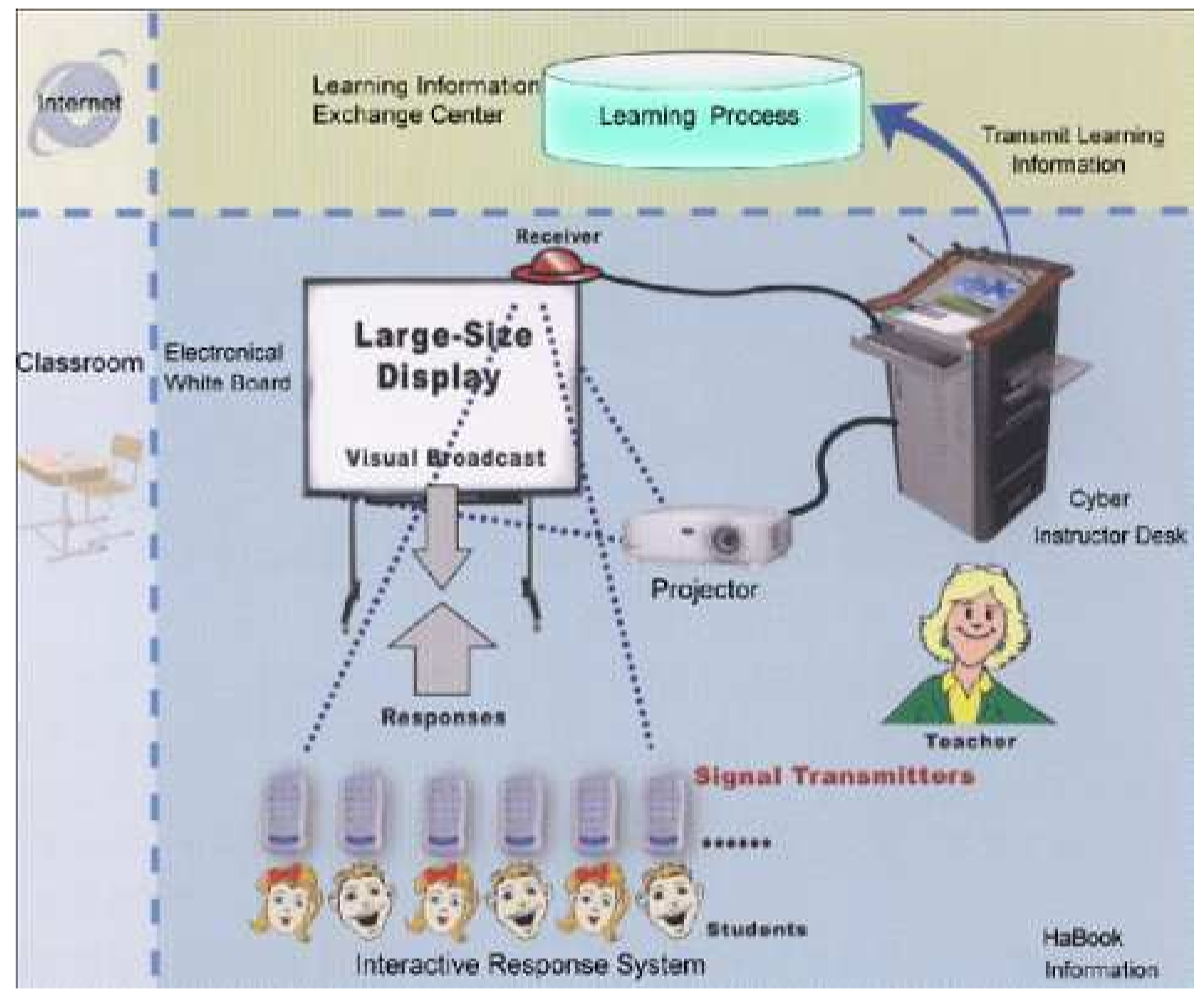

Figure1: Cyber Learning Classroom 


\section{THE PROCEDURE OF PROMOTING PHILOSOPHY OF E-LEARNING}

\section{Setting up Information Communication Technology (ICT) platform:}

We set up Fiber Distributed Data Interface(FDDI) as campus network backbone architecture, and most system servers are established by Linux system. The Figure as follows:

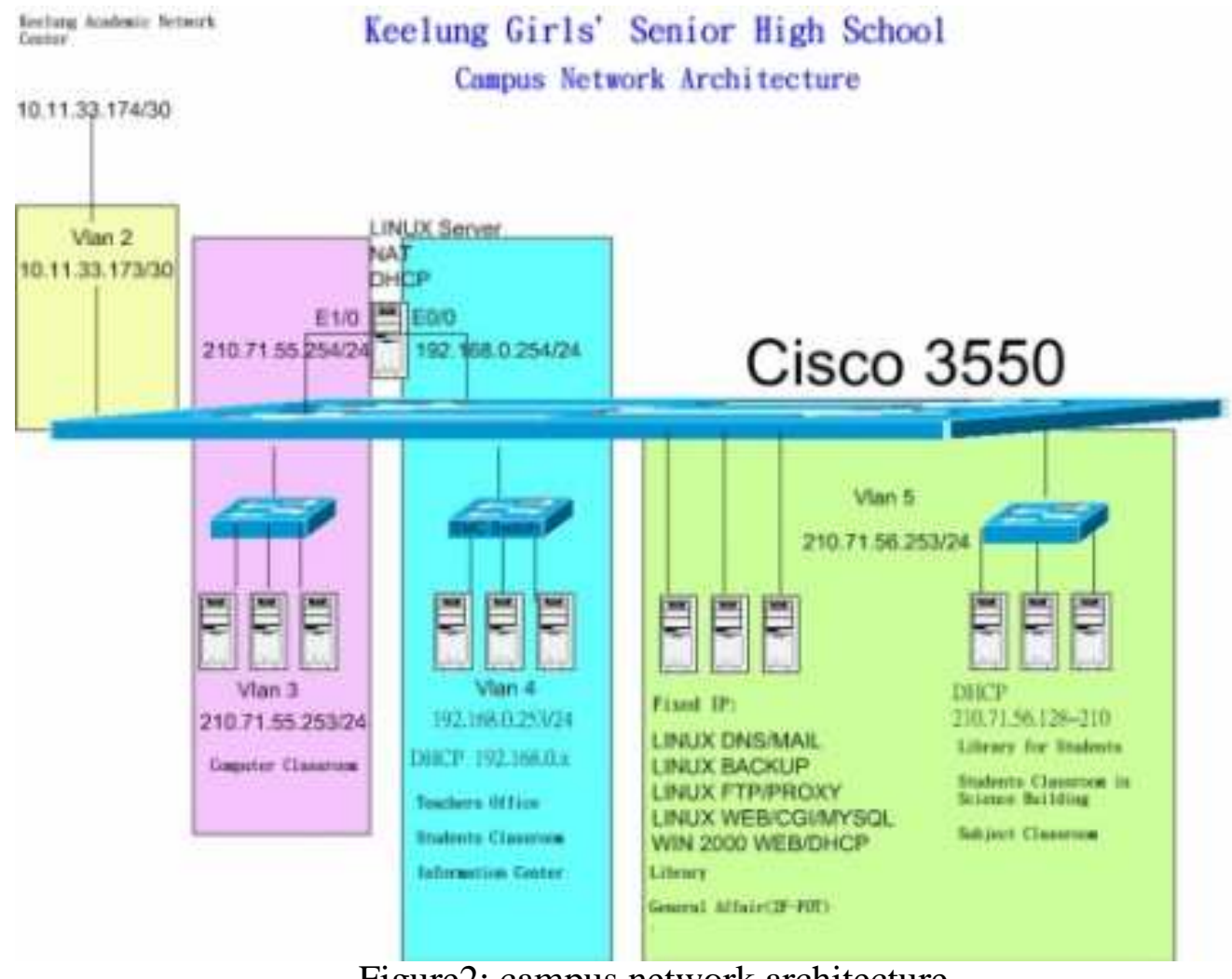

Figure2: campus network architecture

In Keelung area, there are over hundred schools connect to Keelung Academic Network Center(KANC) by FDDI network structure. From KANC connect to Taiwan Academic Network(TANET) by T3. We also set up Wireless Lan in campus, meanwhile, we install DNS, Web Server, E-Mail Server, FTP Server by Linux operating system, and set up Video on Demand Server by Window 2003 Server. As for IP address, we apply for two C class from TANET, it offers 512 fixed IP address.

\section{Setting up Learning Management System(LMS) by HABOOK E-Learning system:}

A learning management system simplifies the process of administering education and training. LMS help create and offer courses and curricula. They reside at the top of the offer column of our tools framework. We integrate software and hardware to promote teaching and learning, as well as building internet solution. By our highly efficient products, the teaching environment is more convenient, and the teaching session is more lively. In this way, there exists a highly interactive relationship between the instructor and the students. Through the aid of internet, the goal of computerized control and intercommunication system can therefore be achieved. These products are such as EZLearning, EduClick, EZTest, EZTeaching...etc. 


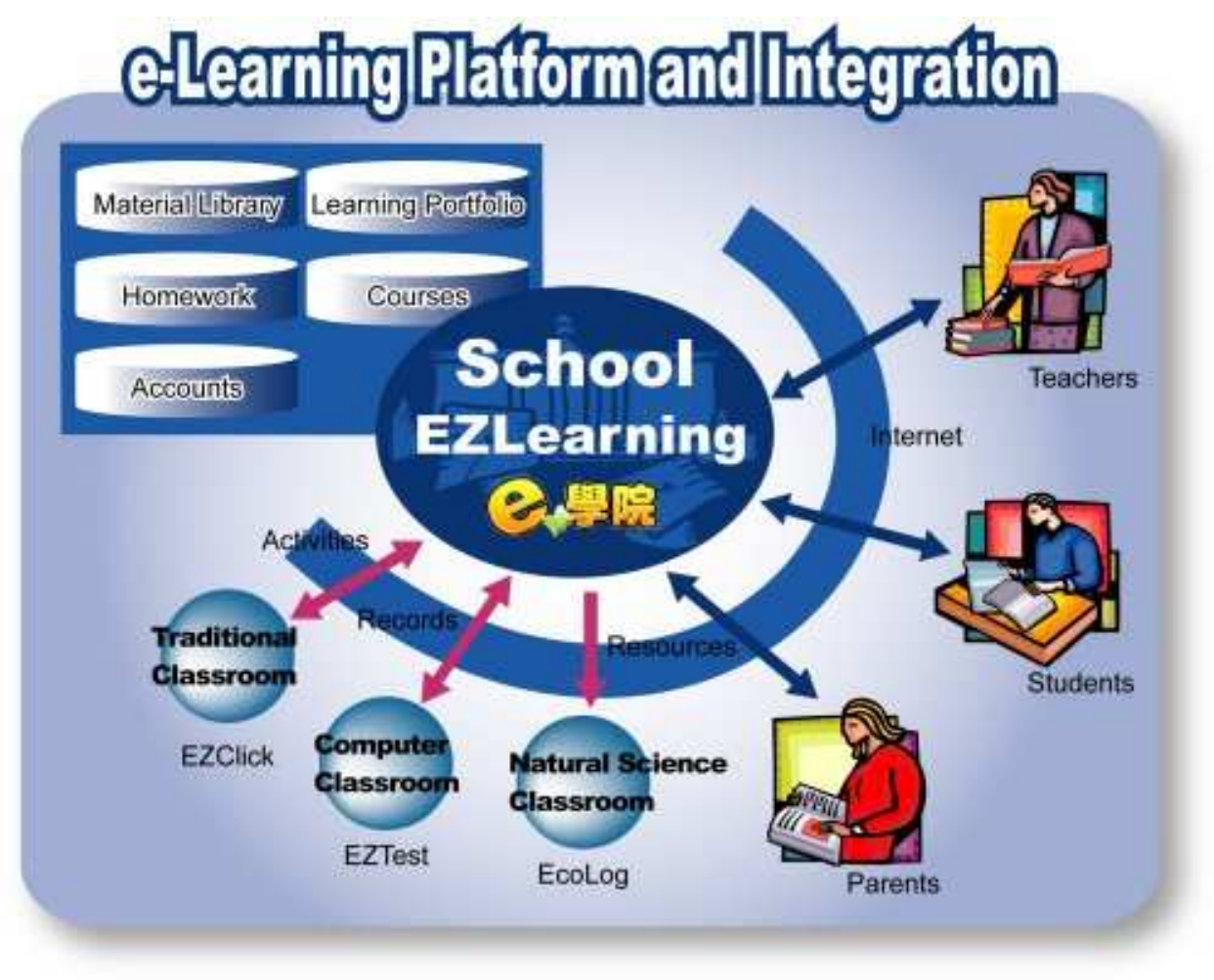

Figure 3: School EZLearning

What is EZLearning.EZLearning is a platform built to help teachers better manage materials, resources and learning results, with this platform students can learn and obtain knowledge through internet activities.

EZLearning is an Internet learning information-integrated center. It's like an e-learning system at school, it is also a platform that supports learning material, manage resources and learning results. With the help of this platform, students can learn and obtain knowledge through internet activities. Not only that the platform supports learning with needed online services, but also combines learning information from internet with classroom work, to help create an e-school learning environment. This platform enables students to continue learning from home, on their own or with their parents. This endows better interaction between teachers, parents and students.

What is EZClick.EZClick - a highly interactive remote instructional system, undoubtedly fits in with the technological learning in classroom environment. EZClick is a combination of software and wireless remote controls used to improve classroom interaction.

The remote controls must be handed out to each student. With the features of EZClick system, instructors can use the software to design media-rich multiple-choice questions. Instructors can create questions ahead of time or they can ask spontaneous questions at any time during the class. 
During the course lecturing, instructor can pose a question to students, along with a set of answer options, all of which is projected on to a large screen. Students response by pressing the corresponding button on the assigned remote controls. Everyone signal from the remote control will hit the infrared receiver to log answer into instructor computer. These answers are instantaneously graded, tallied and analyzed by the system. The results are graphically available to the instructors and students. This function frees instructors from grading papers and compiling statistic.

EZClick is a set of in-class technological tool that promotes students' interests and attentiveness in learning activities. It also meets the rising demand for technology in teaching and learning. Therefore, why not let EZClick play a key role in helping students boost their confidence and learning performances !

What is EZTest.EZTest Highly Interactive Instructional System for Computer Classroom is a system designed for computer classroom, it not only makes learning more exciting but also supports teachers with their exam grading workload.

EZTest Highly Interactive Instructional System for Computer Classroom only needs to be combined with the broadcasting system in order to work. It does not need other hardware and only needs to be installed in the teacher's computer along with internet access. The students can easily complete exams, analyze test results and helps teacher combine final grades, reach the goal of EZ Test and EZ Management : Evaluation, Result analysis, Interactive learning all through EZTest.

\section{Encouraging greater involvement of book-reading clubs among teaching faculty, administrative staff, students and parents:}

It is generally agreed that an uplifting spiritual life of each individual contributes to a more harmonious society. Also, a smooth-running society is a generator that powers the huge machine of society. A resilient mind capable of any internal improvement begin with the willingness of an individual to remove as much as possible the weed of selfishness from his mind. This way, there can be hope for a society teeming with sympathy and compassion. Among the chief cost-efficient results are: individuals are encouraged to invest more time in reading books with a purpose or books that are inspiring. Individuals are also observed to get more involved in experience sharing or discussions of various kinds, to broaden their world of knowledge and to get to know each other better. Starting from year 2000, the central government set the policy of " one class, one book-reading club". Annually, one or sometimes more than one training camp of book-reading club leaders is organized by the school library. A good-quality books exhibition is also on the agenda of the school anniversary. The school principal also takes the leading role in the participation in the book-reading club's activities and the by-product of a better coordination among the administrative is often the result. The Taichung based office of the Ministry of Education also requested National Tainan Girls' Senior High School to hold network 
book-reading club for all senior high school in Taiwan. In Keelung, we have promote this business for 3 years and attend this club's students increases with rate of $30 \%$ every year.

\section{Training seed teachers to promote and popularize Multi-Media Information literacy:}

In Keelung area, there were eight library directors of senior high schools and vocational schools to propose one Keelung area characteristic project for Education Minister and got the fund US $\$ 200,000$ for last two years, so we invited instructors to train seed teachers how to operate multi media tools, PowerPoint - MovieMaker 、Anicam 、 Producer 、 PhotoImpact 、 FLASH - FrontPage etc, to create teaching materials. We prepared five days traing courses twice per year for two years.

Meanwhile, we ask seed teachers to establish and maintain teaching materials in campus web page. We also hold Keelung area Web's Fair contest to invite teachers and students to attend it and offer prize for the masterpiece.

\section{Holding regular contests in web page design • book reading report and evaluation of reading club performance:}

The purposes of holding contests before school's anniversary are evaluation of promoting activities' performance. We also encourage outstanding students to attend contests sponsored by outside of school. In 2004, one team of students obtained the second place of national web page design contest. At least one student gets award from attending national book-reading report contest every year. We offered reward for counselor and students who get the award from attending contest, it makes them more confidence and good for promoting information literacy and book-reading.

\section{Issuing E-newsletters:}

Our school has accumulated two years' experience of issuing e-newsletters. It is our hope that a better-quality, more versatile community e-newsletter will emerge if and when all 13 local academic and vocational senior high schools can work together toward the goal. There sure will be lots of benefits involved, less manpower and greater mutual exchanges among others. More important, it can serve as a platform on which creative issues of special interest can be discussed and the exchange and marketing of issue researches can be made known and made possible. The baffling problem is that an advisory team which is in charge of all academic and vocational senior high schools nationwide already has its own e-newsletter. Insufficient funding has also cornered and stopped the future publication of our e-newsletters. For the time being, all creative-thinking issues and issue-related researches are channeled into the e-newsletters constructed by the aforementioned advisory team. Nevertheless, we are still in firm belief that from a long-term viewpoint, a community-level localized e-newsletter is what is needed to serve as a tool that helps 
boost the idea of marketing creative learning exchanges, provide an incentive to construct a life-learning environment and improve local citizens' capability to confront and handle problems.

\section{Creating Synchronous and Asynchronous Courses:}

If we continually get the fund from Education Minister, we will create the synchronous and asynchronous Courses as follows:

I 、 Asynchrous Courses:

A $、$ Create the following multi-media tutor and training guide in web site:

(1)PowerPoint presentation tool

(2)PhotoImpact image processing tool

(3)PDF document creating, as Acrobat Reader

(4)FrontPage homepage creating tool

(5)Namo Web Editor homepage design tool

(6)Flash animator tool

(7)Captivate tool

(8)Producer tool

(9)VideoStudio multi-media tool

(10)Anicam screen recorder tool

(11)CDex convert CD format to WAV or MP3 format

(12)GoldWave audio editting

B 、To invite instructors to explain how to create teaching materials by above multi-media tools.

II - Synchrous Courses:

Holding the following courses four times per year :

Trainee will learn above asynchrous courses before taking the following courses.

\begin{tabular}{|l|l|l|l|}
\hline no & Subject name & Hours & memo \\
\hline 1 & PhotoImpactimage processing workshop & $3 \mathrm{hrs}$ & \\
\hline 2 & FrontPage homepage workshop & $4 \mathrm{hrs}$ & \\
\hline 3 & $\begin{array}{l}\text { Namo Web Editor web page designing } \\
\text { workshop }\end{array}$ & $3 \mathrm{hrs}$ & \\
\hline 4 & Flash animayor workshop & $7 \mathrm{hrs}$ & \\
\hline 5 & Captivate workshop & $4 \mathrm{hrs}$ & \\
\hline 6 & Producer workshop & $3 \mathrm{hrs}$ & \\
\hline 7 & VideoStudio multi-media tool workshop & $4 \mathrm{hrs}$ & \\
\hline 8 & Anicamscreen recorder workshop & $1 \mathrm{hrs}$ & \\
\hline 9 & Moodle e-learning tool workshop & $6 \mathrm{hrs}$ & \\
\hline
\end{tabular}




\section{OBSTACLES TO BE CONQUERED AND RECOMMENDATIONS}

In Taiwan, all the senior highschools and vocation high schools meet some obstacles in promoting creative learning exchange. So far, we have 3 obstacles to be conquered.

\section{Lack of qualified and certified teachers:}

Courses on systematic thinking process opened and going on at certain colleges and universities are mostly at their initial trial stage. Furthermore, as a result of an acute lack of qualified and certified teachers, the systematic thinking process did not extensively applied to the learning process off other disciplines of science.

\section{Lack of pedagogical approaches:}

Due to an obvious shortage of capable teachers, translated materials that are sufficiently professional and suit the need of the students here are too few in variety and too small in quantity.

\section{Money problems:}

The project is still in its initial, groping-its-way-along phase, with no agency or bureau of any appropriate authority serving as its supervisor, it suffered from a tight budget, which in turn had its grave impact upon the matters of policymaking or performance evaluating. The limited financial resources available usually came as a response to a separate, specific case of research project. Often, and sad to say, we had to rely on the meager appropriation from the school yearly budget.

To confront and conquer the barriers mentioned above, we have come up with the following recommendation:

\section{Creative thinking process be incorporated into the design and development of school curricula.}

Extracurricular clubs with creative thinking process as their core ideas can be started, their performance and results evaluated before finally being integrated into the whole school curriculum.

\section{Institutes be created at local and national levels.}

Such institutes, with promotion of creative thinking process as one of its vital roles, are supposed to hold seminars on a regular basis, to carry out promotion programs and thereby evaluate their performance, to construct web pages and issue e-newsletters, and to hold contests and publish journals.

\section{A sufficient amount of funding be provided.}

To get the necessary funding, the school in charge has to tender: 
(1) Short-term plans regarding seminars on creative-thinking process and workshops of seed-teachers training programs,

(2) Mid-term plans concerning class-teaching demonstrations and related contests,

(3) Long-term plans with focuses on a better pool of teachers, a more definite outline of curricula and a more extensive application in colleges and universities as a selective or required course.

\section{CONCLUSION}

The eventual success will be laid on the groundwork of selfless cooperation on the part of the administrative staff, the teaching faculty, the student body and the students' parents. To make the whole project possible, any and every possible situation has to be taken into account and incentives big and small have to be created. It is something that requires contribution made not only by individuals but also by all involved. The central idea of teaching students to learn how to learn and creative thinking approaches should always be the consistent goal because it is this ultimate capability that arms them in the face of problems and helps with the problem-solving.

It is estimated that a full $25 \%$ of an individual's resources is dedicated to learning in preparation for the challenges in life in a changing world. Such a huge stake of one's resources is absolutely an important and worthwhile investment rather than a meaningless and purposeless waste.

\section{References}

Integrated E-learning---Implications for Pedagogy, Technology and Organization / Wim Jochems, Jeroen van Merrienboer and Rob Koper / RoutledgeFalmer e-Learning---STRATEGIES FOR DELIVERING KNOWLEDGE IN THE DIGITAL AGE / MARC J. ROSENBERG / McGraw-Hill

E-Learning Tools and Technologies / William Horton, Katherine Horton / WILEY

THE ASTD E-LEARNING HANDBOOK---BEST PRACTICES, STRATEGIES, AND CASE STUDIES FOR AN EMERGING FIELD / ALLISON ROSSETT / McGraw-Hill

The Web-Site: www.habook.com.tw/english

Cyber Schooling Framework: Improving Mobility and Situated Learning / Nian-Shing Chen, Kinshuk, Yi-Hung Wang http://native.jfvs.tpc.edu.tw / The web site of Keelung Region Characteristic Project 


\section{Author notes}

Chen, Tzong-Yue

Director of Library

National Keelung Girls' Senior High School in Taiwan

Address : 324 Dung Shin Rd. Keelung, Taiwan

Telephone : 886-2-24278274\#650

E-mail : joneschen@klgsh.kl.edu.tw 